\title{
Kommentar
}

\section{Styring og støtte i moderne governance - samverkan för bästa skola}

Tine S. Prøitz

Institutt for økonomi, historie og samfunnsvitenskap

Universitetet i Sørøst-Norge

I dette temanumret inviteres vi til en svært interessant granskning av den statlige storskala satsingen Samverkan för Bästa Skola (SBS). Satsingen har til målsetting å gi støtte til skoler med lave kunnskapsresultater og som har vanskelige forutsetninger for å forbedre elevenes resultater ${ }^{1}$. Skolene og førskolene som er med i satsingen er spesielt utvalgte av Skolverket basert på tilgjengelig informasjon og statistikk. Ordningen har en tydelig uttalt målsetting om å tilby støtte og hjelp til førskoler og skoler som strever med å imøtekomme myndighetenes krav.

Nærblikket på SBS som artiklene i dette temanumret presenterer viser at satsingen omfatter høy grad av kompleksitet. Studiene synliggiør spesielt hvor viktig det er å problematisere spenningsforhold som følger av statlige satsinger der både det å styre og det å støtte inngår. Satsingen involverer aktører $\mathrm{i}$ hele det svenske utdanningssystemet inkludert forskere og konsulenter. Målsettinger og arbeidsprosesser er formidlet på ulike måter i ulike typer av styringsdokumenter og planer. Satsingen innebærer forventinger om fortolkning, operasjonalisering, re-fortolkning og reoperasjonalisering av et nasjonalt budskap på tvers av utdanningssystemets nivåer. Samtidig omfatter SBS også prosessforløp med helt bestemte prosedyrer, bruk av bestemte verktøy for analyse og tolkning av bestemte data som skal gi aktørene et grunnlag for utvikling. SBS omfatter også et språk der begreper som for eksempel «uppbyggning av kapacitet», «förmåga till 
självförbättring» og «att utvecklas utifrån sina egna behov», «samarbete» og «samverkan» står sentralt.

SBS som statlig satsing føyer seg inn i en rekke av liknende policy initiativ vi kan se i Norden og internasjonalt (se for eksempel Meyers \& Murphy, 2007; Murphy, 2009; Utdanningsdirektoratet 2020). Dette er initiativ som har til hensikt å sørge for at førskoler, skoler og barn og unge som ikke når opp til definerte standarder satt for virksomhetene skal bringes opp på et akseptabelt nivå. Et kjennetegn ved slike initiativ er at de ofte er utformet som frivillige tilbud eller som en invitasjon til å få støtte og hjelp til å ta tak i egen situasjon gjennom samverkan med utdanningsmyndigheter og eksperter.

SBS som fenomen er, som studiene i dette temanumret viser, en så rik case at det finnes et mangfold av tema å reflektere over. I denne refleksjonsartikkelen har jeg valgt å konsentrere meg om spenningsforholdet mellom det å styre og støtte i moderne governance ut fra tre overskrifter inspirert av artiklene i dette nummeret av PfS: styring og støtte, top-down og bottom up perspektiver og læreren i politikk og praksis.

\section{STYRING OG STØTTE I MODERNE GOVERNANCE}

Statlige reformer og tiltak i dag har gjerne et flersidig moment. Dels handler det om oppriktige ønsker om å gi støtte og hjelp og tilførsel av nødvendig kunnskap og ressurser. Dels handler det om å styre for å sikre at virksomheter som ikke leverer på definerte mål og som har negativ utvikling blir bragt inn i linjen. Dette er altså innsatser med en dobbel funksjon gjennom både å fungere som støtte og som styring av lærere og skole (se for eksempel Kirsten, 2020). Samtidig bærer denne dobbeltheten med seg flere dilemmaer for den som styrer og støtter og for den som blir styrt og støttet.

Dobbeltheten kan forstås å ha sitt opphav i hvordan offentlig politikk og tenkning omkring styring har utviklet seg de siste tiårene. I tradisjonell hierarkisk og byråkratisk tenkning har styringen til intensjon å oppnå en bestemt virkning og effekt gjennom pålegg, direktiv og resultatkontroll. I dag ser vi imidlertid gjerne også en annen type styring i form av såkalt governance. Governance kan forstås som samspill og samordning mellom strukturer og prosesser, mellom institusjoner og aktører og mellom regler og bruk av regler (Pollitt \& Hupe, 2011).

På den ene siden peker det moderne governance begrepet på svekkelsen av statlig makt og styring blant annet som konsekvens av en generell økt kompleksitet i samfunnets strukturer, empiriske studier som viser at slik sentral styring ikke virker så godt, og som konsekvens av en generell ideologisk og kunnskapsmessig utvikling i samfunnet i stort. På den andre siden henviser governance til en forståelse av samfunnsaktører som ressurser og instrumenter i såkalt co produced public policy making fremfor å anse 
aktørene som passive mål og subjekter for offentlig styring (se for eksempel Ansell \& Torfing, 2016). Denne tenkningen kan også knyttes til utviklingen av post-liberale ideer om utviklingen av aktive medborgere og post-moderne desentering av makt som vi for eksempel kan se i desentraliserte systemer. Governance tenkningen baserer seg også på ideer om «the regulated selfregulation» der myndigheter som styrer på distanse ønsker å legge til rette for og regulere aktørers interaksjon innenfor mer autonome arenaer (Sørensen \& Triantafillou, 2009). I slik interaktiv styring av samfunnet blir kollektivt fremforhandlede mål viktige blant annet fordi ingen aktør har kunnskap, ressurser og kapasiteter nok til å styre alene $\mathrm{i}$ vår tids komplekse og fragmenterte samfunn. (Kooiman, 1993). Innenfor utdanningsfeltet kan vi finne bidrag som har likhetstrekk med denne type tenkning hos for eksempel Ball som anser politikk å være komplekse, kontekstuelle og institusjonelle diskursive prosesser. Politikk gjøres av og med lærere som både aktører og subjekter, subjekter i og objekter av policy (Ball, 2012, s.4). Eller hos Spillane og Coburn der skoleledere og lærere forstås som sentrale aktører med innvirkning på policy og $\mathrm{i}$ policy formation gjennom å være viktige iverksettere og fortolkere av policy i praksis (se for eksempel Coburn \& Turner, 2011; Spillane m.fl., 2011). Det pekt på at det moderne governance begrepet er nyttig og komplekst, men også et «slippery» begrep kjennetegnet av begrepsmessig flertydighet, det er normativt attraktivt, det har en global salgbarhet og en tendens til å dekke over og fornekte konflikter mellom ulike aktørgrupper (Pollitt \& Hupe, 2011).

Studiene presentert i dette temanumret viser at svenske myndigheter kommuniserer en form for styring basert på idealer om støtte gjennom samarbete og samverkan. Studiene viser også at det finnes en tydelig asymmetri i samverkansrelasjonene. Myndighetene definerer hvem som har behov for støtte og hvem som skal inviteres inn og hvem og hva som skal få finansiering. Myndighetene bestemmer også grunnlaget for problemdefineringen så vel som problemene, og har løsningene på hvilke arbeidsprosesser og verktøy som er nødvendige og skal tas i bruk for at skolene og lærerne skal utvikle en «förmåga til selvförbättring».

Det er et således et spørsmål om hva samverkan i denne sammenheng betyr? Hvilken rolle har aktørene fått og hvorfor? Studiene presentert her peker på at myndighetenes støtte har karakter av styring og kontroll og at det synes vanskelig å finne balansen i rollen som både støttende myndighet på den ene siden og styrende myndighet på den andre siden. Sett opp mot et moderne governance perspektiv der aktørene kan ses som aktive ressurser kan vi stille spørsmål om dette er arbeidsprosesser som gir skolens aktører det handlingsrommet, den selvstendigheten, motivasjonen og eierskapet de trenger til å kunne se seg selv som viktig ressurs i problemdefinering, fortolkning og beslutningstaking for eget arbeid? 


\section{TOP-DOWN OG BOTTOM-UP OG BEHOVET FOR NYE ANALYTISKE BLIKK}

Samverkan, co-production og samskaping (som vi særlig ser brukt i Norge) er ord i tiden som på den ene siden indikerer prosesser der aktørenes perspektiver kan møtes på likefot og føre til gjensidig utvikling. På den annen side er dette også begreper som kan bidra til å tilsløre styringselementet i moderne governance. Slik tilsløring kan bidra til å konservere eksisterende maktstrukturer og asymmetriske forhold som ikke ivaretar alle aktørenes perspektiver. Flere av artiklene i dette temanumret tar i bruk og diskuterer velkjente perspektiver på hvordan reformer formes og gjennomføres, og hvordan forholdet mellom forvaltningsnivåer og institusjoner kan forstås som top-down/ovenfra og ned (hierarki), og bottom up/nedenfra og opp (kollegium) og politikk som læring (nettverk). Perspektivene gir gode muligheter for analyse av strukturer og aktørenes roller, og hvordan nivåer, institusjoner og aktører genererer, tolker, og implementerer pålegg. De gir også et godt grunnlag for å vurdere hvilke implementeringsstrategier som tas i bruk av statlige myndigheter (Aasen m.fl., 2012).

Om vi legger til grunn en forståelse av forholdet mellom nivåene i utdanningssystemet ut fra et politisk maktperspektiv der utdanning er et iboende politisk prosjekt og en arena hvor makropolitiske krefter definerer rammebetingelsene for aktørenes handlinger på mikronivå blir det viktig med analytiske perspektiver som kan kaste lys over politikkens premisser og konsekvenser når styringen skifter form og fokus. Når forholdet mellom det statlige og det lokale endres, som i moderne governance, er det nødvendig å diskutere om våre eksisterende analytiske perspektiver er gode nok for å analysere nyere former for policy og governance karakterisert av samverkan, samskaping og co-production. Når myndigheter inviterer aktørene inn $i$ utviklingen av policy, i prosesser om problem- og måldefinering og tilbyr støtte og hjelp til selvhjelp og skoleutvikling hvilke konsekvenser får det for aktørenes roller? Hva blir styring og autonomi under slike vilkår? Hvem har for eksempel ansvaret for de beslutninger som tas i slike samverkasrelasjoner? Med nye statlige tiltak basert på samverkan der myndigheter har en sentral rolle i prosessene kan det se ut til at vi trenger nye analytiske begreper og perspektiver. Dette må være begreper og perspektiver som makter å ivareta kompleksiteten $\mathrm{i}$ moderne governance når den går utover idealmodellenes tradisjonelle forståelser av roller og ansvar hos stat, myndighet, huvudman, skoleleder og lærer.

\section{LÆREREN SOM AKTØR I POLITIKK OG PRAKSIS}

Et gjennomgående trekk i studiene presentert her og i mye av forskningen på reformer, policy og styring er at vi ofte studerer strukturene og organisasjon- 
ene ved å se på dokumenter og planer, vi intervjuer administra-sjon og ledere. Til tross for et økt fokus på læreprofesjonalitet i den resultat-orienterte skolen forsker vi i begrenset grad på skolen og lærerens aktiviteter og praksis, læreres fortolkninger og praksisteorier når vi skal studere statlige satsinger, policy og styring (se for eksempel Prøitz m.fl., 2017).

Dette er interessant med tanke på at myndigheter innenfor moderne governance styrer etter mål og resultater og ved hjelp av data, analyser, selvevalueringer, åtgjärdsplaner ol. som i stor grad blir til i skjæringspunktet mellom lokale myndigheter og skolens, skolelederes og læreres praksiser. Studiene $\mathrm{i}$ dette temanumret viser at styringen og samverkan $\mathrm{i}$ SBS når helt frem til læreren og har til hensikt å berøre lærerens praksis gjennom sine bestemte utvalgskriterier, prosesser, verktøy og prosedyrer. Dette samsvarer med forskning og pågående policy prosesser i Norge der myndighetene også styrer og støtter gjennom såkalte samskapingsprosesser i implementering av nytt planverk for barnehage og nye lærerplaner i den nyereformen av skolen Fagfornyelsen (Utdanningsdirektoratet, 2018a, 2018b). Hva slike forventinger og idealer om samverkan/samskaping gjør med de ulike aktørene i skolen, lærerrollen, lærerens profesjonalitet, handlefrihet og arbeidsglede vet vi foreløpig ikke så mye om. Det er empiriske spørsmål som må utforskes i skjæringspunktet mellom politikk og praksis. Det kreves forskning og perspektiver som kan ta høyde for at skolen formes mellom uklare kategorier for styring og støtte. Dette krever at vi som forskere må involvere skolens aktører og deres perspektiver $\mathrm{i}$ bredere forstand, også når vi studerer storskala satsinger og policy reformer for å kunne sikre at forskning på moderne governance ivaretar betydningen av at samverkan og samskaping er uttalte policy elementer.

\section{SAMVERKAN FÖR BÄSTA SKOLA}

Artiklene i dette temanumret av PfS gir et veldig interessant innblikk i et eksempel på utdanningsmyndigheters anstrengelser på å bringe alle barn, lærere og skoler opp på det som anses å være et akseptabelt nivå i forhold til definerte standarder. SBS er et omfattende og krevende policy initiativ som involverer aktører på alle nivå i det svenske utdanningssystemet. Studiene som presenteres her gir en god mulighet til å reflektere over forholdet mellom politikk og praksis. De gir også viktige bidrag til å diskutere moderne governance og våre forståelser av forholdet mellom overordnet beslutningsnivå og lokal operasjonalisering når forholdet beskrives som samverkan, samskaping eller co-construction. I flere av artiklene berøres SBS uttalte grunnide som at myndighetenes eksterne støtte vil fostre lokalt initiativ og utvikle «förmåga till självförbättring" gjennom samverkan. Samverkan kan anses å ha fått en nøytraliserende funksjon i det klart asymmetriske forholdet som finnes mellom nasjonal besluttende myndighet og lokal utøver. Retorikken handler om å tilby støtte og samverka for videre positiv utvikling 
samtidig som problemdefinering, finansiering, initiativ og arbeidsprosesser blir bestemt av SBS. Artiklene viser tydelig hvordan det i SBS legges til grunn en språklighet om samverkan som utfordrer våre tradisjonelle oppfatninger om en hierarkisk struktur for organisering og styring av skolen, at det finnes et over og et under og at vi kan studere dette ved å innta et top-down eller bottom-up perspektiv. Samtidig viser studiene av SBS at programideene om lokalt initiativ og självforbättring ut fra skolens egne behov ikke helt slippes løs og at myndighetene forsøker å minimere avvik ved å sikre «rett» forståelse av SBS hele veien ut i skolen. Innenfor en slik fortolkning er det fare for at myndighetene ender opp med tradisjonell styring $\mathrm{i}$ «samverkans-utkledning», og kanskje til og med sterkere styring enn opprinnelig tenkt. I moderne governance teorier er den aktive medborger som ressurs i offentlig politikkutforming mer enn retorikk og en nødvendighet for legitimitet gjennom kollektive beslutningsprosesser. I sin ytterste konsekvens utfordrer dette våre oppfatninger av utdanningssystemets hierarki, rolleforståelse og ansvarsdeling når samverkan ser ut til å sammenføye det overordnede og det underordnede og roller og ansvar blir uklare. Samverkan som ideal, ambisjon og aktivitet i moderne governance gir således grunnlag for en rekke nye spørsmål når det gjelder utviklingen av skolen. I dette temanumret presenteres fire høyaktuelle studier av forholdet mellom overordnet beslutning og lokal operasjonalisering for en videre diskusjon om styring og støtte gjennom samverkan for utvikling av skolen.

\section{NOTER}

${ }^{1}$ Se informasjon om satsingen på Skolverkets web, lastet ned 070421 https://www.skolverket.se/skolutveckling/leda-och-organisera-skolan/samverkanfor-basta-skola

\section{REFERANSER}

Ansell, Christopher, \& Torfing, Jacob (red.). (2016). Handbook on theories of governance. Edward Elgar Publishing. https://www.e-elgar.com/shop/gbp/handbook-ontheories-of-governance-9781782548492.html

Aasen, Petter, Møller, Jorunn, Rye, Ellen, Ottesen, Eli, Prøitz, Tine Sophie, \& Hertzberg, Frøydis (2012). Kunnskapsløftet som styringsreform - et løft eller et løfte? Forvaltningsnivåenes og institusjonenes rolle i implementeringen av reformen. Oslo, Nifu. https://nifu.brage.unit.no/nifuxmlui/handle/11250/280885

Ball, Stephen J. (2012). Politics and policy making in education: Explorations in sociology. Routledge. 
Coburn, Cynthia E., \& Turner, Erica O. (2011). Research on data use: A framework and analysis. Measurement: Interdisciplinary Research \& Perspective, 9(4), 173-206.

Kirsten, Nils (2020). Kompetensutveckling som styrning: Om statliga insatser för lärares kompetensutveckling och hur de förhandlas i lärares lokala praktik (Doctoral dissertation). Acta Universitatis Upsaliensis.

Kooiman, Jan (Red.). (1993). Modern governance: new government-society interactions. Sage.

Meyers, Coby V., \& Murphy, Joseph (2007). Turning around failing schools: An analysis. Journal of School Leadership, 17(5), 631-659.

Murphy, Joseph (2009). Turning around failing schools: Policy insights from the corporate, government, and nonprofit sectors. Educational Policy, 23(6), 796-830.

Pollitt, Christopher, \& Hupe, Peter (2011). Talking about government: The role of magic concepts. Public Management Review, 13(5), 641-658.

Prøitz, Tine Sophie., Mausethagen, Sølvi, \& Skedsmo, Guri (2017). Investigative modes in research on data use in education. Nordic Journal of Studies in Educational Policy, 3(1), 42-55.

Spillane, James P., Parise, Leigh M., \& Sherer, Jennifer Z. (2011). Organizational routines as coupling mechanisms: Policy, school administration, and the technical core. American educational research journal, 48(3), 586-619.

Sørensen, Eva, \& Triantafillou, Peter (2009). The politics of self-governance: an introduction. The politics of self-governance, $1(1)$. http://202.166.170.213:8080/xmlui/bitstream/handle/123456789/3127/\%20Th $\mathrm{e} \% 20$ politics $\% 20$ of $\% 20$ self-governance.pdf?sequence $=1$ \&isAllowed $=y \#$ page $=14$

Utdanningsdirektoratet (2018a) Webinar Implementering gjennom samskaping ved Irgens, hentet 8 november 2020 fra internett, https://www.udir.no/laring-ogtrivsel/stottemateriell-til-rammeplanen/webinar-implementering-gjennomsamskaping/

Utdanningsdirektoratet (2018b) Fagfornyelsen og nye læreplaner for yrkesfag, hentet 8 november 2020 fra internett, https://www.udir.no/globalassets/filer/vurdering/vfl/presentasjoner/dagskonfe ranser_18/oslo/om-fagfornyelsen.pdf

Utdanningsdirektoratet (2020) Oppfølgingsordningen, hentet 8 november 2020 fra internett https://www.udir.no/kvalitet-og-kompetanse/lokalkompetanseutvikling/oppfolgingsordningen/ 